\title{
Optimal extraction of photovoltaic energy using fuzzy logic control for maximum power point tracking technique
}

\author{
Kadhim Hamzah Chalok ${ }^{1}$, Mohammad Faridun Naim Tajuddin², Thanikanti Sudhakar Babu ${ }^{3}$, \\ Shahrin Md Ayob ${ }^{4}$, Tole Sutikno 5 \\ ${ }^{1,2}$ School of Electrical Systems Engineering, Universiti Malaysia Perlis, Perlis, Malaysia \\ ${ }^{3}$ Department of Electrical Power Engineering, Universiti Tenaga Nasional, Kajang, Malaysia \\ ${ }^{4}$ School of Electrical Engineering, Faculty of Engineering, Universiti Teknologi Malaysia, Johor Bahru, Malaysia \\ ${ }^{5}$ Department of Electrical Engineering, Universitas Ahmad Dahlan, Yogyakarta, Indonesia \\ ${ }^{5}$ Embedded System and Power Electronics Research Group, Yogyakarta, Indonesia
}

\section{Article Info}

Article history:

Received Jan 29, 2020

Revised Apr 26, 2020

Accepted May 3, 2020

\section{Keywords:}

DC-DC boost converter

Fuzzy logic controller

Maximum power point tracking

Photovoltaic

\begin{abstract}
In photovoltaic (PV) systems, maximum power point tracking (MPPT) techniques are used to track the maximum power from the PV array under the change in irradiance and temperature conditions. The perturb and observe $(\mathrm{P} \& \mathrm{O})$ is one of the most widely used MPPT techniques in recent times due to its simple implementation and improved performance. However, the P\&O has limitations such as oscillation around the MPP during which time the $\mathrm{P} \& \mathrm{O}$ algorithm will become confused due to rapidly changing atmospheric conditions. To overcome the above limitation, this paper uses the fuzzy logic controller (FLC) to track the maximum power from the PV system under different irradiance, integrates it with a DC-DC boost converter as a tracker. The result of the FLC performance is compared with the traditional P\&O method and shows the MPPT algorithm based on FLC ensures continuous tracking of the maximum power within a short period compared with the traditional $\mathrm{P} \& \mathrm{O}$ method. Besides that, the proposed method (FLC) has a faster dynamic response and low oscillations at the operating point around the MPP under steady-state conditions and dynamic change in irradiance.
\end{abstract}

This is an open access article under the CC BY-SA license.

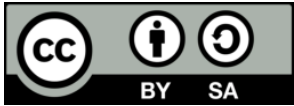

\section{Corresponding Author:}

Mohammad Faridun Naim Tajuddin, School of Electrical Systems Engineering, Universiti Malaysia Perlis (UniMAP), Sg. Chuchuh, Arau, Jalan Wang Ulu, 01000 Kangar, Perlis, Malaysia Email: faridun@unimap.edu.my

\section{INTRODUCTION}

Currently, there is a high demand for developing a non-polluting, alternative and renewable source of energy in the universe. The potentiality of utilising renewable energy sources (solar or wind energy) promises a valuable source of renewable energy. Generating electric power from the solar photovoltaic (PV) panels depends on different factors such as the panel temperature, operating conditions, presence of shadow, and solar irradiance, among others. Sunlight is the leading environmental source of supplying solar energy due to many nuclear reactions that take place on the sun's surface. This type of energy is perhaps the most well-known renewable resource that is most exploited. Many current technologies extract electrical energy from solar irradiations. The devices that can convert sunlight to electric power are called PV [1].

These PV cells generate energy from sunlight. When the photons contact with the PV cells, the PV cells release electrons, and when the cell was connected to the circuit, electric energy will be generated. Solar technology uses passive and active techniques to convert sunlight into useful energy [2]. The PV cells exhibit 
non-linear I-V characteristics. The maximum power could be tracked from PV panels if it is operated at the maximum power point (MPP). Various techniques are utilised to track the maximum power by operating these panels at the MPP. Such techniques are described as MPP tracking (MPPT) methods.

MPPT techniques were used to run the PV modules on the maximum power, which were classified as (1) conventional methods (2) soft computing methods. The conventional MPPT methods include the P\&O [3-6], incremental conductance [7-10], fractional short circuit current [11, 12] and the fractional open circuit voltage [13,14]. These conventional MPPT processes were very effective under uniform and steady environmental conditions. In the case of the PV systems that operate under uniform conditions, it exhibits one MPP, and it may get the change to identify multiple peaks due to changes in irradiation and temperature conditions.

The MPP can be determined using conventional processes. These techniques show continuous oscillation around the MPP, which leads to power loss. The traditional MPPT cannot track the global MPP under non-uniform conditions and cannot handle the partial shading conditions [15]. The major drawbacks of conventional MPPT methods can be resolved using soft computing processes. Some of the primary principles of these soft computing methods include uncertainty, robustness, and partial truth. The soft computing methods can handle the non-linear issues, and offer better solutions for the MPPT [16]. The widely used soft computing processes are particle swarm optimization [17-20], artificial neural network [21, 22] and the fuzzy logic controller [23-25].

The perturb and observe $(\mathrm{P} \& \mathrm{O})$ algorithm is used extensively owing to its low computational demand, simple implementation and less cost. Further, under varying atmospheric conditions, the $\mathrm{P} \& \mathrm{O}$ algorithm produces oscillations around the MPP. On the other hand, during rapid change in the irradiance, the algorithm shifted away from the MPP and produces huge power drop of the available energy. In such a case, the algorithm could not differentiate between the numerous variations seen in the output power as caused by its voltage perturbation or rapid irradiation changes. Thus, some changes had to be made in the algorithm to overcome these problems [26].

In recent years, fuzzy logic controllers (FLC) were used to control the small and smooth fluctuations in the signals which led to steady-state conditions [27]. These required few computation steps, which raises the efficiency and speed of the technique. The FLCs can maintain the MPP under different irradiation values [28].

In this paper, the authors proposed an innovative using FLC by developing an MPPT algorithm for the PV system. The proposed technique is evaluated under the steady-state and dynamic shade conditions. Further, tracking speed after that the FLC algorithm performance is compared with the traditional P\&O algorithm to show the superiority of the method.

\section{MATHEMATICAL MODEL OF A PV CELL}

Many models have been described to achieve the properties of the PV cell, i.e. the single diode model [29], double diode model [30] and three diode models [31]. These models are developed based on mathematical equations [32] that use similar circuit equations as those used by the PV cells. These equations trade accuracy for complexity. A single diode model is one of the simplest models; it is based on the single current source and the diode. This model is extended to develop a double exponential model having shunt resistances and equivalent series. In this work, we use a standard single exponential model that includes shunt resistance as shown in Figure 1 [33].

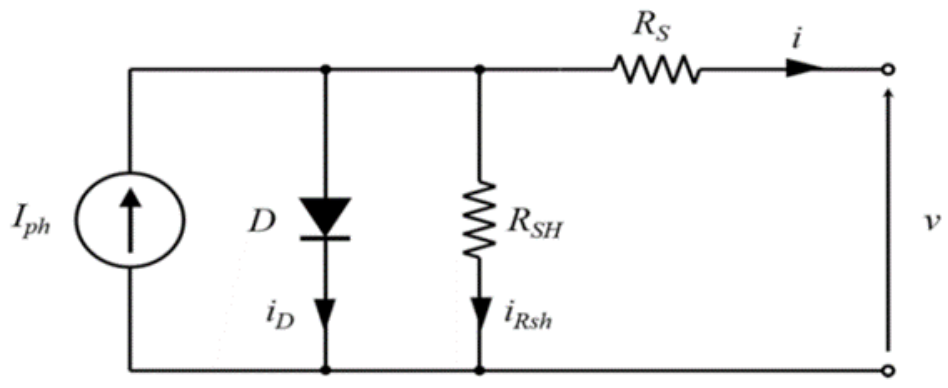

Figure 1. Equivalent solar PV circuit model with a series, shunt resistor and single diode

The current, $I_{p h}$, is the photocurrent in the cell; $I_{o}$ is the PV saturation current; while $R_{s}$ and $R_{s h}$ represent the series resistances and intrinsic shunt, respectively. The $R_{S}$ is generally neglected for simplicity

Optimal extraction of photovoltaic energy using fuzzy logic control for ... (Kadhim Hamzah Chalok) 
in analysis as the $R_{s h}$ value is larger than $R_{s}$ value. To increase the current and voltage, the PV cells are connected in series and parallel to form the module. When the modules are connected in a parallel-series configuration, it can be treated as the PV array. In (1-4) describe the mathematical module of the PV panel [34].

The PV photocurrent, $I_{p h}$, is determined as:

$$
I_{\mathrm{ph}}=\left[I_{\mathrm{SCr}}+\mathrm{Ki}\left(T-T_{r}\right)\right] * \frac{S}{1000}
$$

The reverse saturation, Irs, is calculated as:

$$
I_{\mathrm{rs}}=\frac{I_{\mathrm{SCr}}}{\left[\exp \left(\frac{q V o c}{N s k A T}\right)-1\right]}
$$

The PV saturation current, $I s$, is determined as:

$$
I_{S}=I_{\mathrm{rs}}\left[\frac{T}{T_{r}}\right]^{3} \exp \left[\frac{\mathrm{qEg}}{\mathrm{Ak}}\left(\frac{1}{T_{r}}-\frac{1}{T}\right)\right]
$$

The PV output current, $I_{p v}$, is estimated as:

$$
I_{\mathrm{pv}}=\mathrm{Np}^{*} \mathrm{I}_{\mathrm{ph}}-\mathrm{Np}^{*} \mathrm{I}_{\mathrm{ph}}\left[\exp \left\{\frac{\mathrm{q}^{*} \mathrm{~V}_{\mathrm{pv}}+I_{\mathrm{pv}} \mathrm{Rs}}{\mathrm{NskAT}}\right\}-1\right]
$$

The nonlinear equation of PV characteristic depends on the temperature and irradiance of the solar cell. Under standard test conditions where the cell temperature is $25^{\circ} \mathrm{C}$ and the irradiance is $1000 \mathrm{~W} / \mathrm{m}^{2}$, the PV module manufacturers usually receive specified data as references. The characteristic curves are shown in Figure 2 (a), Figure 2 (b) and Figure 3(a), Figure 3(b). Figure 2 illustrates the $I-V$ and $P$ - $V$ characteristic curves under differing irradiance conditions and Figure 3 illustrates the $I-V$ and $P-V$ characteristic curves under differing temperatures.

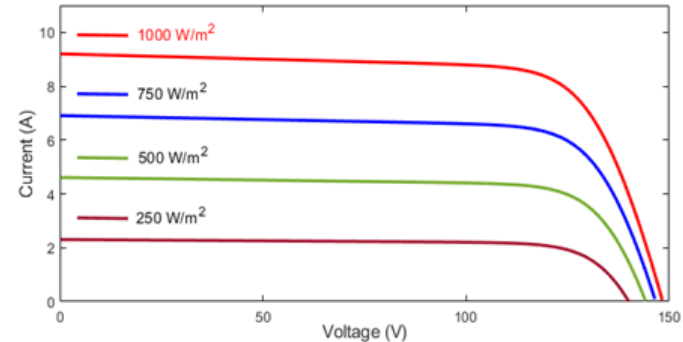

(a)

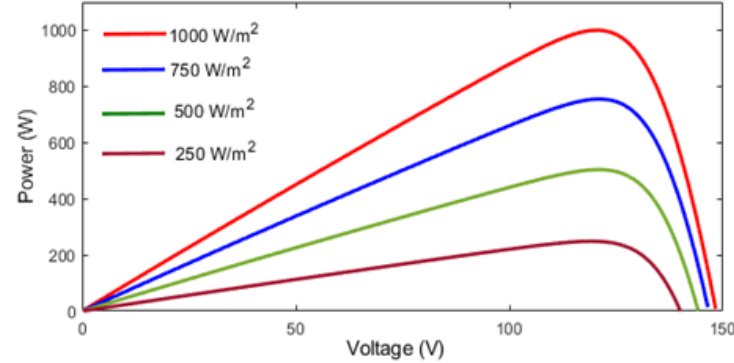

(b)

Figure 2. The characteristic curves for different irradiances; (a) $I-V$ characteristic (b) $P$ - $V$ characteristic

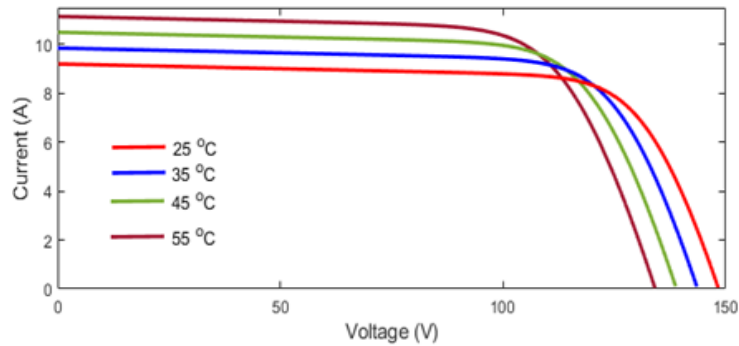

(a)

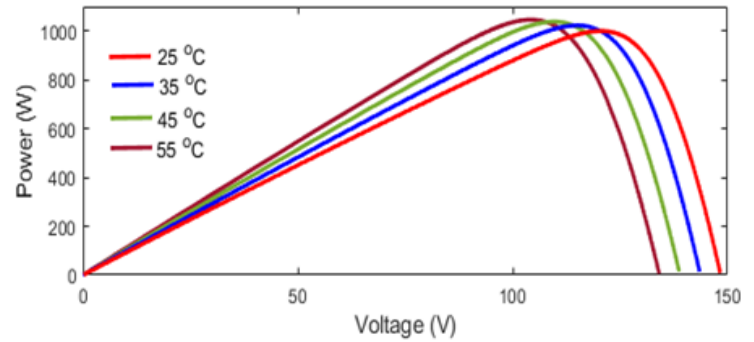

(b)

Figure 3. The characteristics curves for different temperatures; (a) $I-V$ characteristic (b) $P$ - $V$ characteristic 
The authors used the JWP 250W DESERT (HIP Solar GmbH, Germany) solar PV module in this work to carry-out the experimentations. Four solar panels are connected in the $4 \times 1(\mathrm{~S} \times \mathrm{P})$ configuration to form a PV array with output power $1 \mathrm{KW}$. Table 1 shows the parameters of specifications of the PV array and module. Figure 4 presents the block diagram of a complete PV system configuration including the MPPT controller.

Table 1. The parameters of specifications of the JWP 250W DESERT module and array

\begin{tabular}{ccc}
\hline Parameters & Module & PV array $\left(4^{*} 1\right)$ \\
\hline Maximum power point $\left(P_{m p p}\right)$ & $250 \mathrm{~W}$ & $1000 \mathrm{~W}$ \\
Maximum current $\left(I_{m p p}\right)$ & $8.30 \mathrm{~A}$ & $8.30 \mathrm{~A}$ \\
Voltage maximum $\left(V_{m p}\right)$ & $30.12 \mathrm{~V}$ & $120.5 \mathrm{~A}$ \\
Short-circuit current $\left(I_{s c}\right)$ & $9.20 \mathrm{~A}$ & $9.20 \mathrm{~A}$ \\
Open-circuit voltage $\left(V_{o c}\right)$ & $37.10 \mathrm{~V}$ & $148.4 \mathrm{~V}$ \\
Temperature coefficient of $V_{o c}$ & $-0.118 \mathrm{~V} / \mathrm{C}$ & $-0.118 \mathrm{~V} / \mathrm{C}$ \\
Temperature coefficient of $I_{s c}$ & $0.065 \mathrm{~A} / \mathrm{C}$ & $0.065 \mathrm{~A} / \mathrm{C}$ \\
Number of cells & 60 & 240 \\
\hline
\end{tabular}

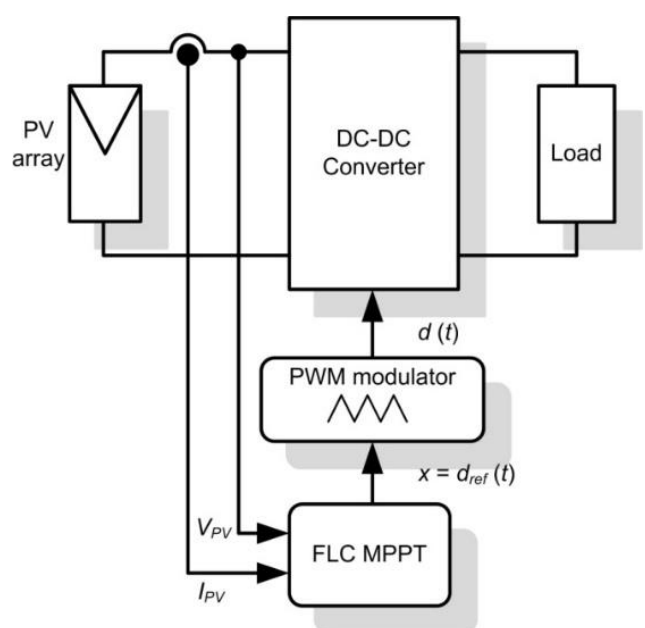

Figure 4. Block diagram describing the PV system

\section{DC-DC BOOST CONVERTER}

A DC-DC boost converter is utilised in the PV system as it is an adaptable and efficient MPPT controller. This converter has helped to control a voltage output that is higher than the voltage input. Figure 5 shows the transistor in the DC-DC boost converter, which regulates the enhanced processing by the controller. A MOSFET transistor was utilized in this converter. In (5) defines the circuit's voltage gain [35].

$$
\frac{V_{o}}{V_{i}}=\frac{1}{(1+D)}
$$

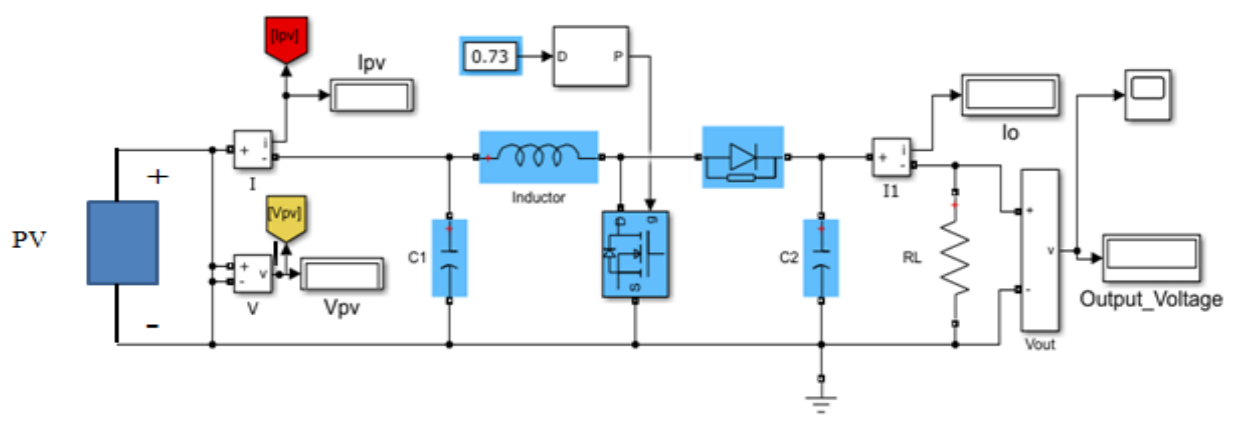

Figure 5. Circuit diagram of the DC-DC boost converter 
Where: $V_{o}$ : converter output voltage, $V i$ : converter input voltage, $D$ : duty cycle. DC-DC boost converter that is controlled by the gate driver circuit. The working principle of the DC-DC boost converter can be divided into two parts. The first part is when MOSFET was switched ON; the inductor (L) current direction flowed in reverse while the inductor stored the energy and generated a magnetic field, whereas the output capacitor $\left(\mathrm{C}_{2}\right)$ transferred the energy to an inverter. In the second part, the transistor was switched OFF, wherein the main source and energy would be connected in series [36]. The DC-DC boost converter design employed in this study is specified in Table. 2

\begin{tabular}{cc} 
Table 2. The parameters of the DC-DC boost converter \\
\hline Elements & Values \\
\hline Inductor & $332.625 \mu \mathrm{H}$ \\
MOSFET & $1 \mathrm{RF} \mathrm{P} 460$ \\
Power Diode & IN 5408 \\
Capacitor, $\mathrm{C}_{2}$ & $9.125 \mu \mathrm{f}$ \\
Resistive Load & $200 \Omega$ \\
Frequency & $20 \mathrm{kHz}$ \\
Input capacitance, $\mathrm{C}_{1}$ & $5 \mathrm{mF}$ \\
\hline
\end{tabular}

\section{MPPT FUZZY LOGIC CONTROLLER}

The proposed FLC technique is used to overcome common drawbacks of the conventional MPPT technique like the loss of tracking during dynamic changes in irradiance and oscillation during steady-state conditions. FLC is one of the most effective control techniques and has attracted a lot of interest in a wide range of applications. The FLC is utilised to improve the performance of the MPPT in PV systems by enhancing its tracking capability to deal with the non-linearity characteristics of the PV array. For this purpose, the duty-cycle of the boost converter is controlled by the FLC rules, if the perturbation in the duty cycle increased the power, the next direction of perturbation must be moved in the same direction. On the other hand, if the power is decreased, the direction of the duty cycle perturbation should be in the opposite direction.

Figure 6 presents the flowchart for the FLC algorithm. This algorithm was based on three major steps, i.e., (1) fuzzification, (2) inference and, (3) defuzzification. In the case of fuzzification, this algorithm substituted the numerical input value into the linguistic variables that are presented as the membership functions. Thereafter, the inference step relates the output and input information, whereas the defuzzification step transformed the output information into a numerical value [37].

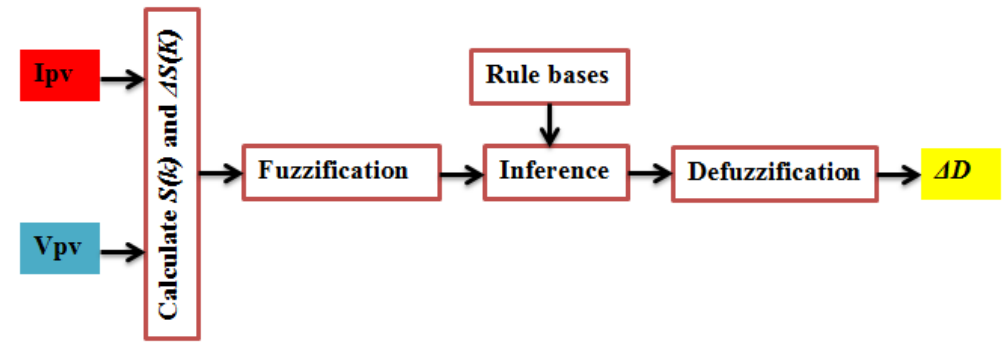

Figure 6. Steps involved in the Fuzzy logic algorithm

In this work, the Slope of P-V (the error) and the Variation of Slope (change of error) are utilised as input values $(\mathrm{S}(\mathrm{k})$ and $\Delta \mathrm{S}(\mathrm{K}))$ for the FLC system. The error $(\mathrm{S}(\mathrm{k}))$ and the change of error $(\Delta \mathrm{S}(\mathrm{k}))$ in the PV modules are used as fuzzy input variables. These variables are expressed as follows:

$$
\begin{aligned}
& S(k)=\frac{\Delta P_{P V}}{\Delta V_{P V}}=\frac{I_{P V}(k) V_{P V}(k)-I_{P V}(k-1) V_{P V}(k-1)}{V_{P V}(k)-V_{P V}(k-1)} \\
& \Delta S(k)=S(k)-S(k-1)
\end{aligned}
$$

Figure 7 presents the database which is used for the fuzzy rules that are based on input variables for fuzzy. A 5-term fuzzy set of variables, i.e., Negative Big (NB), Negative Small (NS), Zero (ZE), Positive Big (PB) and Positive Small (PS) are employed to describe every linguistic variable. The outputs from the fuzzy 
controller (i.e., duty cycle ratio command of a boost converter) changed the output current and voltage values of a PV module. After these values are changed, they will affect the fuzzy input variables values of the second set. Thereafter, the output commands will be re-adjusted by the controller. The fuzzy logic system also stated that the selection of the domain including the input and output values (i.e., the universe of discourse) would significantly affect the results, hence, appropriate designs have to be implemented. A few guidelines which help in defining the membership functions such as: (1) Defining the limitations between the NB and PB regions based on the characteristics of all input variables; (2) ZE range was based on the specified MPPT objective (efficiency criteria); and (3) Limitations of the PM and NM were determined after selecting

the

$\mathrm{PB}$, Figure 8(a), Figure 8(b) and Figure 8(c) describe the input and output fuzzy logic membership functions.

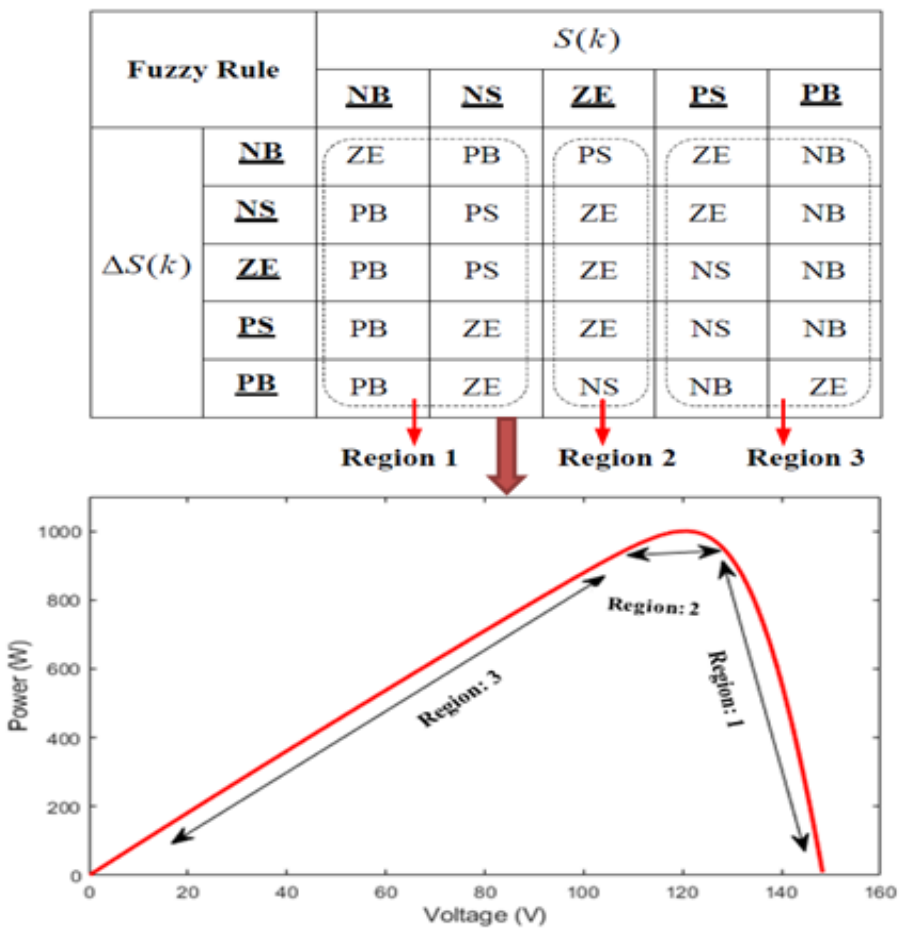

Figure 7. Fuzzy rules used for the error and changes of error used as inputs

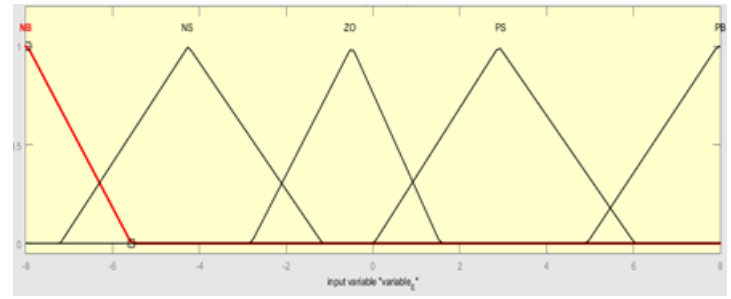

(a)

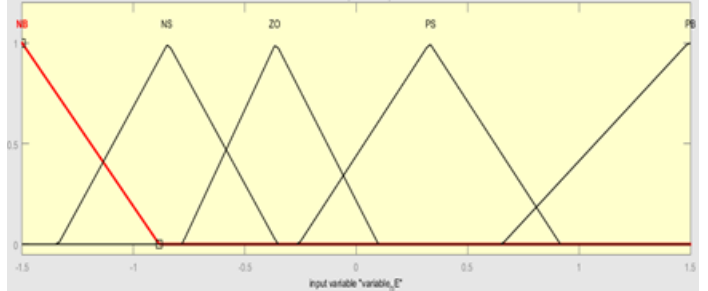

(b)

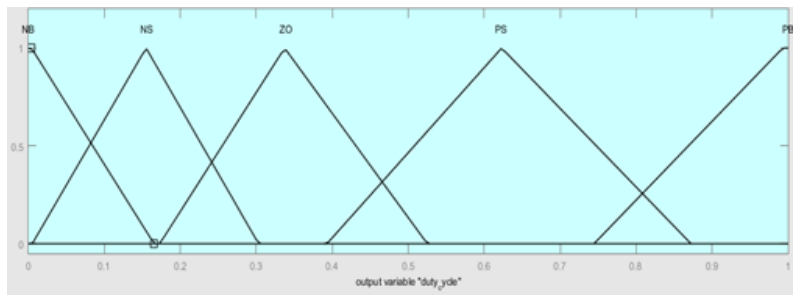

(c) 
Figure 8. The membership functions used for (a) Error $\mathrm{S}(\mathrm{k})$ (b) Change of error $\Delta \mathrm{S}(\mathrm{k}$ ) (c) Duty cycle $\Delta \mathrm{D}$

Figure. 9 presents the MATLAB/Simulink ${ }^{\circledR}$ model of the MPPT controller. The block diagram for an MPPT is based on the method proposed in this study. This model includes the initial duty cycle, where the PV array voltage and current are measured and power is estimated. Figure 10 depicts the model that has been implemented using MATLAB/Simulink®

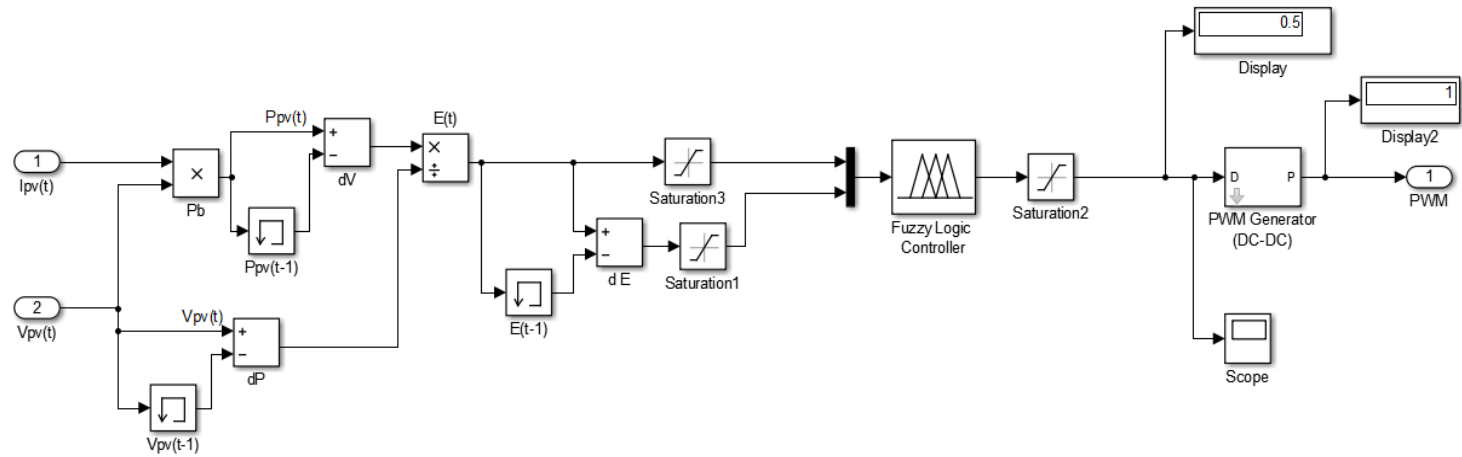

Figure 9. Simulink model of the FLC MPPT algorithm

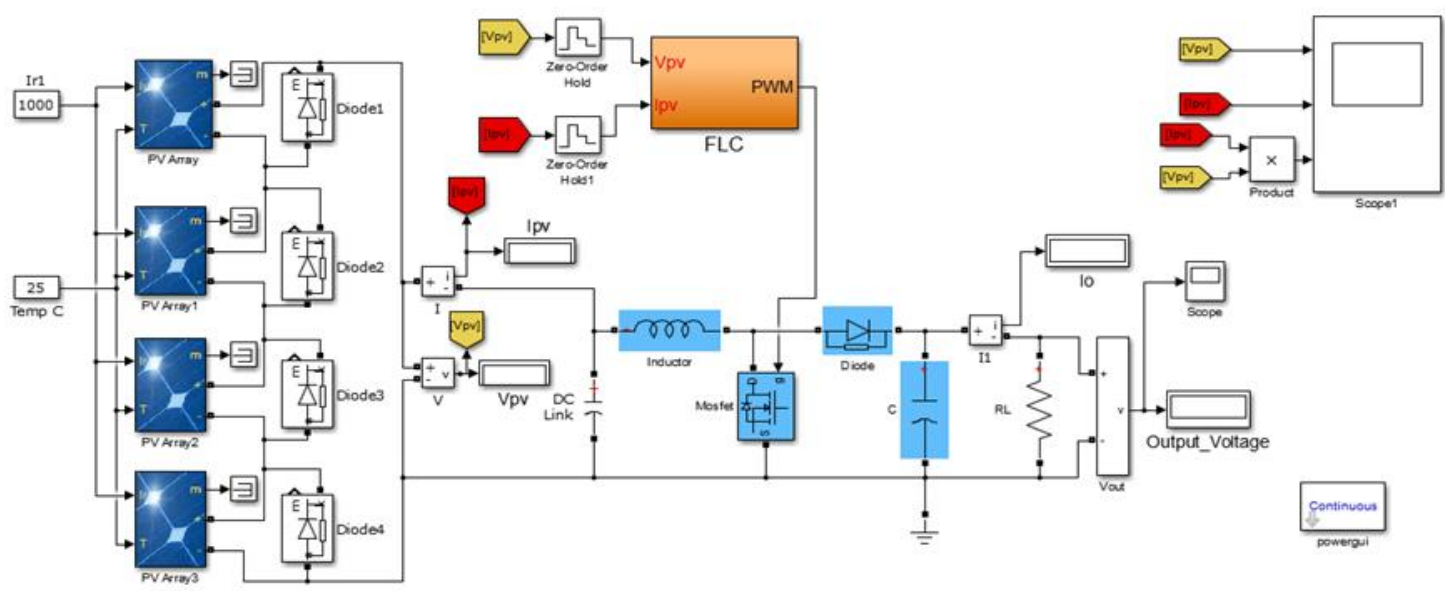

Figure 10. Modelling systems through simulink environment

\section{RESULTS AND DISCUSSION}

The tracking abilities of the proposed FLC-MPPT algorithm is examined under two conditions, i.e., (1) steady-state conditions; and (2) dynamic changes in the irradiance. Thereafter, the performance of the proposed algorithm is examined with the traditional $\mathrm{P} \& \mathrm{O}$ algorithm.

\subsection{Performance under steady-state conditions}

At irradiance of $900 \mathrm{~W} / \mathrm{m}^{2}$ as shown in Figure 11(a), Figure 11(b) and Figure 11(c), the output power from the PV array is $902.76 \mathrm{~W}$. In this case, the proposed FLC-MPPT algorithm succeeded to make the operating point of the system at the maximum point within $0.082 \mathrm{sec}$.

The tracking performance of the traditional $\mathrm{P} \& \mathrm{O}$ method at the irradiance value of $900 \mathrm{~W} / \mathrm{m}^{2}$ achieved the MPP within $0.151 \mathrm{sec}$. The results show that the proposed FLC-MPPT technique incurred fewer oscillations, a stable operating point and the proposed FLC-MPPT algorithm possessed higher accuracy than the P\&O method when it is operated at the MPP value.

At irradiance of $600 \mathrm{~W} / \mathrm{m}^{2}$ as shown in Figure 12(a), Figure 12(b) and Figure 12(c), the proposed FLC successfully tracked the MPP within $0.137 \mathrm{sec}$. The power extracted from the PV array under this irradiance is $604.937 \mathrm{~W}$ 


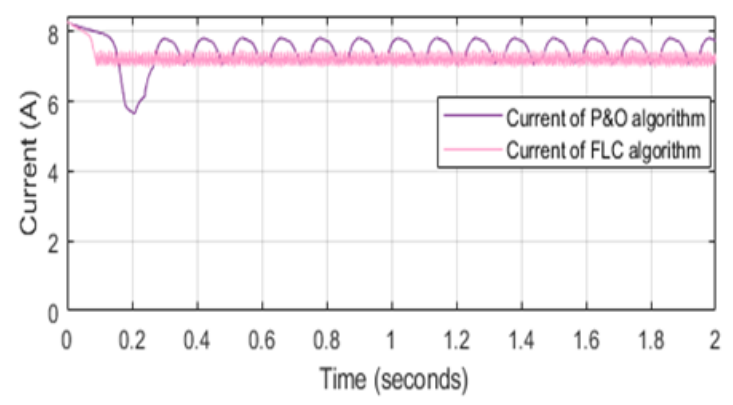

(a)

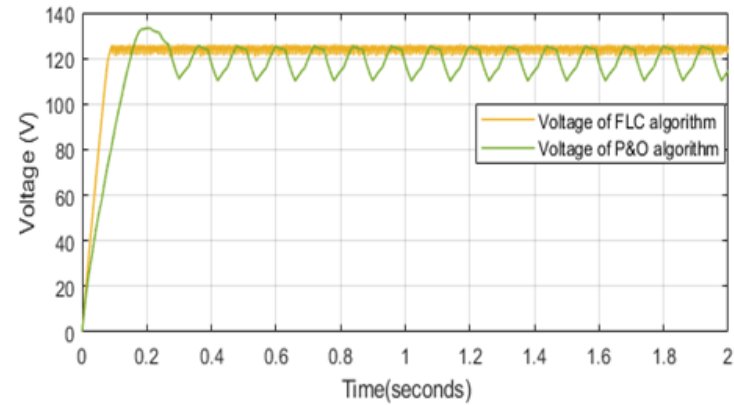

(b)

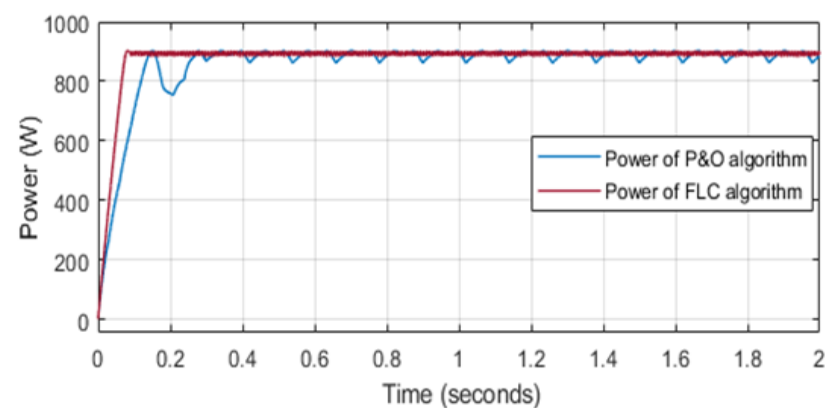

(c)

Figure 11. Tracking performance of the FLC-MPPT and P\&O technique at an irradiance of $900 \mathrm{~W} / \mathrm{m}^{2}$ (a) Current (A) (b) Voltage (V) (c) Power (W)

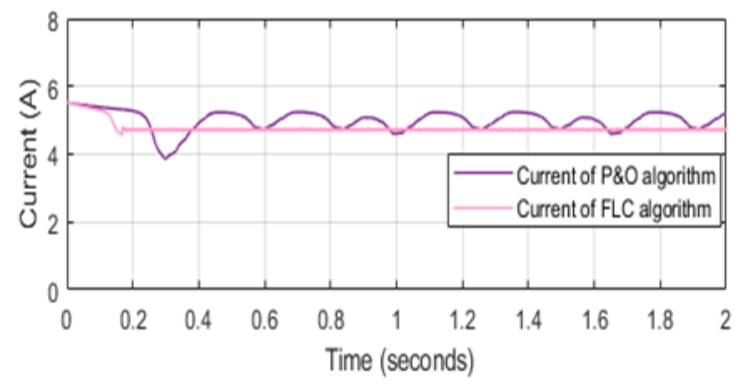

(a)

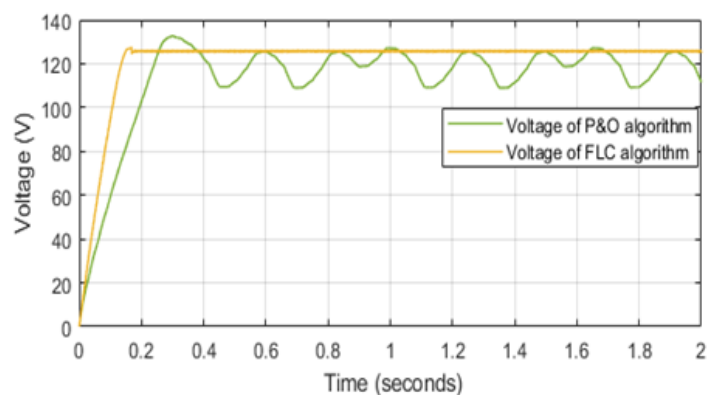

(b)

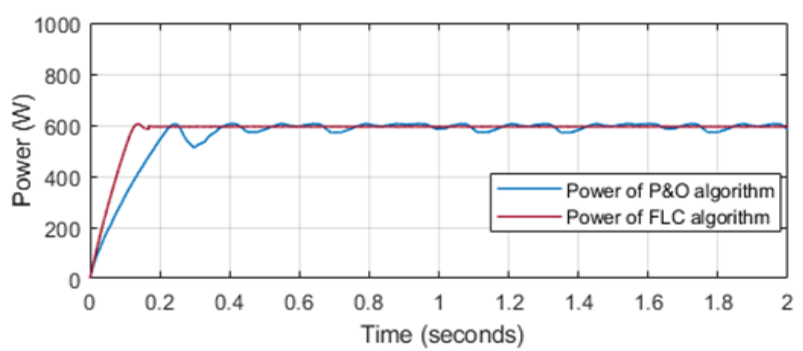

(c)

Figure 12. Tracking performance of the FLC-MPPT and P\&O technique at an irradiance of $600 \mathrm{~W} / \mathrm{m}^{2}$ (a) Current (A) (b) Voltage (V) (c) Power (W)

The conventional P\&O algorithm successfully tracked the MPP within $0.244 \mathrm{sec}$ for the irradiance of $600 \mathrm{~W} / \mathrm{m}^{2}$. The extracted power from the PV array under this irradiance is $604.937 \mathrm{~W}$. In this test, P\&O needs more time than the previous condition because the step-size value is smaller. Table 3 presents the comparison of the tracking results derived after a comparative evaluation of the proposed FLC-MPPT and 
traditional $\mathrm{P} \& \mathrm{O}$ techniques. This performance is compared with regards to the harvesting power, the time required for reaching the maximum power under the steady-state conditions.

Table 3. Comparison of the tracking results for the proposed FLC-MPPT and the conventional P\&O methods

\begin{tabular}{ccccc}
\hline Irradiance & MPPT Algorithm & $\begin{array}{c}\text { Theoretical maximum } \\
\text { power }\end{array}$ & Extracted Power & Time of tracking \\
\hline $900 \mathrm{~W} / \mathrm{m}^{2}$ & Proposed FLC method & $903 \mathrm{~W}$ & $902.764 \mathrm{~W}$ & $0.082 \mathrm{~s}$ \\
& P\&O method & $903 \mathrm{~W}$ & $902.764 \mathrm{~W}$ & $0.151 \mathrm{~s}$ \\
$600 \mathrm{~W} / \mathrm{m}^{2}$ & Proposed FLC method & $605 \mathrm{~W}$ & $604.937 \mathrm{~W}$ & $0.137 \mathrm{~s}$ \\
& P\&O method & $605 \mathrm{~W}$ & $604.937 \mathrm{~W}$ & $0.244 \mathrm{~s}$ \\
\hline
\end{tabular}

\subsection{Performance analysis dynamic change in irradiance condition}

In the first case, as can be seen in Figure 13(a), Figure 13(b)and Figure 13(c), the irradiance starts at $600 \mathrm{~W} / \mathrm{m}^{2}$ until 0.5 seconds. In the 0.5 second, there was a one-step change from $600 \mathrm{~W} / \mathrm{m} 2$ to $800 \mathrm{~W} / \mathrm{m} 2$, and on the one-second, another step change from $800 \mathrm{~W} / \mathrm{m}^{2}$ to $1000 \mathrm{~W} / \mathrm{m}^{2}$. The proposed FLC method and $\mathrm{P} \& \mathrm{O}$ technique are tested under an irradiance profile shown in Figure 14.

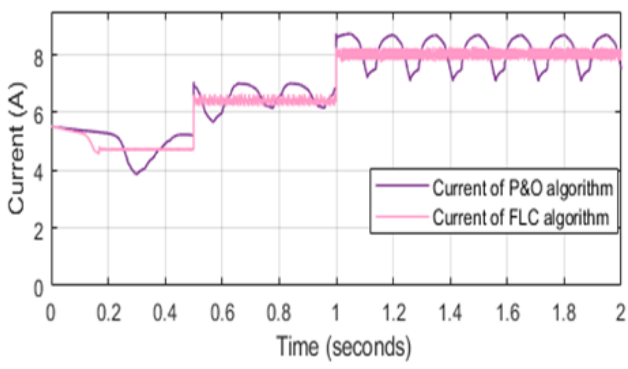

(a)

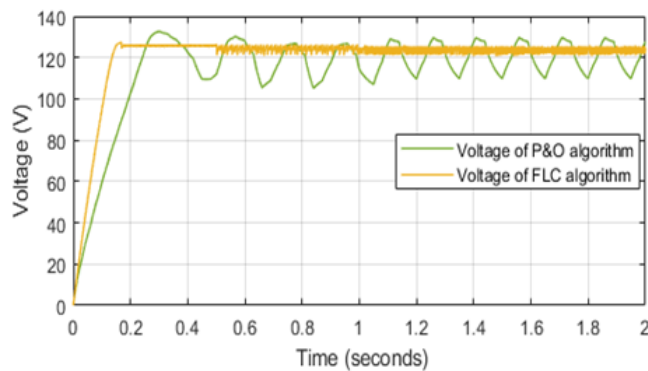

(b)

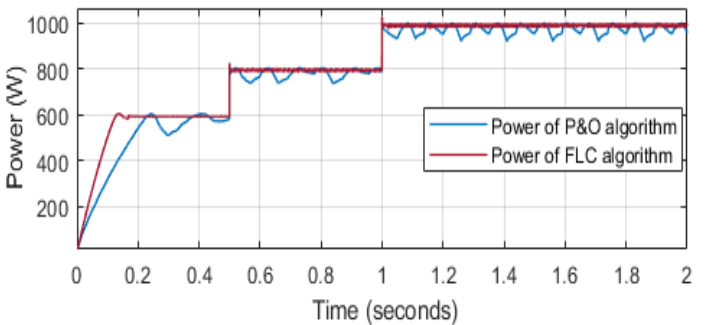

(c)

Figure 13. Tracking the performance of the FLC-MPPT and P\&O technique under dynamic changes occurring in the irradiance at the step-up changes of $200 \mathrm{~W} / \mathrm{m}^{2}$ (a) Current (A) (b) Voltage (V)

(c) Power (W)

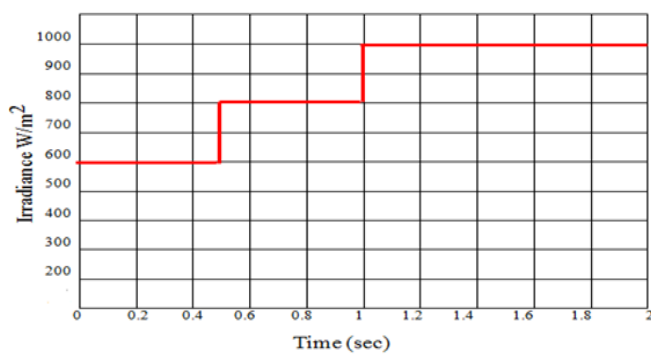

Figure 14. An irradiance profile for dynamic test

For the proposed FLC method, the MPP tracking time is only $0.137 \mathrm{sec}$ and the power extracted is $604.937 \mathrm{~W}$. After step-changing to the $800 \mathrm{~W} / \mathrm{m}^{2}$, the MPP is reached within $0.009 \mathrm{sec}$ and the power extracted of $804.518 \mathrm{~W}$. For $1000 \mathrm{~W} / \mathrm{m}^{2}$, the power extracted is 999.708 within $0.009 \mathrm{sec}$. And for the 
conventional P\&O method, the tracking time of $600 \mathrm{~W} / \mathrm{m}^{2}$ irradiance is $0.244 \mathrm{sec}$ for the $800 \mathrm{~W} / \mathrm{m}^{2}$ irradiance is $0.025 \mathrm{sec}$ and 0.085 for the $1000 \mathrm{~W} / \mathrm{m}^{2}$ irradiance. The output power from the PV array is $595 \mathrm{~W}$ for the 600 $\mathrm{W} / \mathrm{m}^{2}$ irradiances, $796.12 \mathrm{~W}$ for the $800 \mathrm{~W} / \mathrm{m}^{2}$ irradiances and $995.76 \mathrm{~W}$ within $0.085 \mathrm{sec}$ for $1000 \mathrm{~W} / \mathrm{m}^{2}$ irradiance conditions. As observed from Figure 14, the tracking performance using the proposed FLC method is faster and more stable than the conventional P\&O method. Table 4 illustrates a comparison of the tracking results seen after applying the proposed FLC and conventional P\&O methods when the irradiance is subjected to a step-up of $200 \mathrm{~W} / \mathrm{m}^{2}$. The second case of the dynamic change in irradiance test is a sudden step-down in irradiance, as shown in Figure 15.

In this case, the irradiance decreases by a step of $200 \mathrm{~W} / \mathrm{m}^{2}$ for five-time starting from $1000 \mathrm{~W} / \mathrm{m}^{2}$ until $200 \mathrm{~W} / \mathrm{m}^{2}$. The performance tracking of the proposed FLC method and conventional P\&O method can be observed from the output power scheme illustrated in Figures 16(a), Figures 16(b) and Figures 16(c).

Table 4. Comparison of the tracking results seen after applying the proposed FLC and conventional P\&O methods when the irradiance is subjected to a step-up of $200 \mathrm{~W} / \mathrm{m}^{2}$

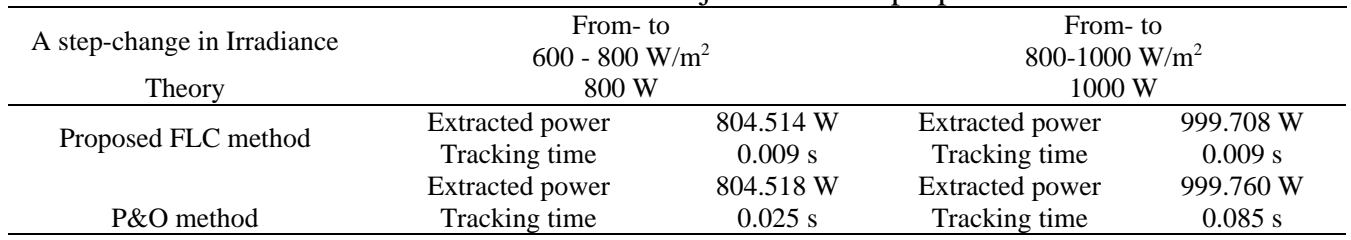

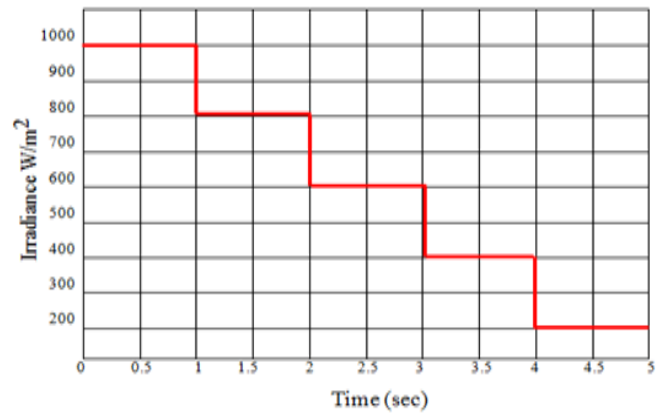

Figure 15. Step-down sudden changes occurring in the irradiance

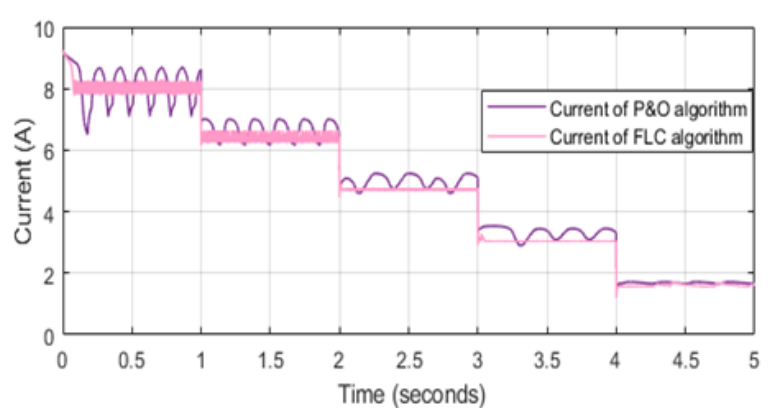

(a)

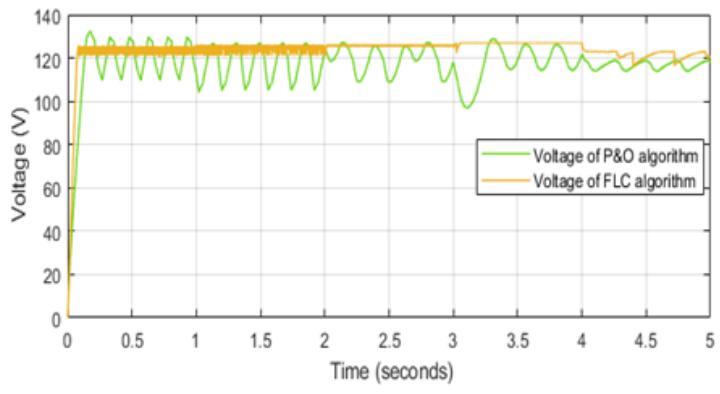

(b)

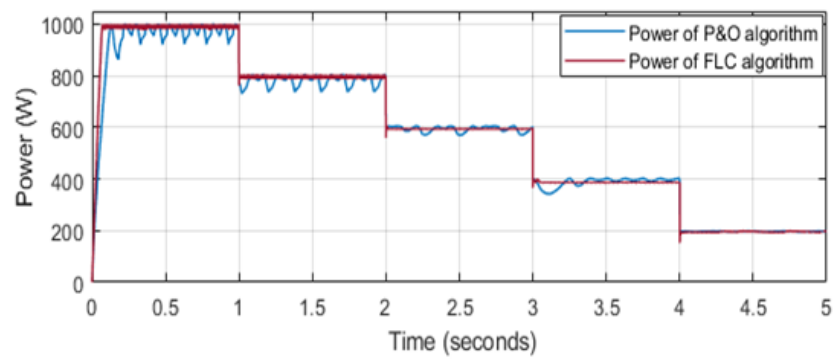

(c) 
Figure 16. Tracking the performance of the FLC-MPPT and P\&O technique under dynamic changes occurring in the irradiance at the step-down changes of $200 \mathrm{~W} / \mathrm{m}^{2}$; (a) Current (A) (b) Voltage (V)

(c) Power (W)

It is evident that the algorithm based on the proposed method can track the irradiance profile comprehensively with minimum oscillation at the beginning of the procedure and without losing the tracking. On the other hand, the amplitude of the oscillation of the conventional P\&O method is continuous. Furthermore, the conventional $\mathrm{P} \& \mathrm{O}$ method incurs time lost in its tracking direction.

\section{CONCLUSION}

In this paper, an MPPT based on the fuzzy logic algorithm is developed. The mathematical model of the PV array has been extensively described. The DC-DC boost converter model and MPPT based FLC have been developed through Matlab simulation package. To validate the design of the proposed MPPT, simulation works under several irradiance conditions i.e. dynamic change and steady-states have been conducted. The results showed superior performance as compared to the conventional P\&O method. The FLC algorithm proposed in this paper has eliminate the steady-state oscillation at the output side of the PV. Furthermore, it was shown that the proposed FLC algorithm extracts a higher amount of power than the conventional $\mathrm{P} \& \mathrm{O}$ techniques in a short period when the irradiance underwent steady-state and dynamic changes.

\section{ACKNOWLEDGEMENT}

The authors would like to thank the Universiti Malaysia Perlis and the ministry of higher education (MOHE) Malaysia for providing the facilities and financial support (Fundamental research grant scheme (FRGS) under a grant number of FRGS/1/2018/TK07/UNIMAP/02/1

\section{REFERENCES}

[1] M. Aureliano et al., "Evaluation of the Main MPPT Techniques for Photovoltaic Applications," IEEE transactions on industrial electronics, vol. 60, no. 3, pp. 1156-1167, 2013.

[2] G. Fernandez and V. Krishnasamy, "Fuzzy logic based duty cycle estimation for Maximum Power Point Tracking in Photovoltaic Systems,” J. Adv. Res. Dyn. Control Syst., vol. 07, no. June, 2018.

[3] S. Sreekumar, "Maximum Power Point Tracking of Photovoltaic System Using Fuzzy Logic," International Conference on Current Trends in Engineering and Technology, 2013.

[4] D. Kumar and K. Chatterjee, "A review of conventional and advanced MPPT algorithms for wind energy systems," Renew. Sustain. Energy Rev., vol. 55, pp. 957-970, 2016.

[5] Amirullah and A. Kiswantono, "Power quality enhancement of integration photovoltaic generator to grid under variable solar irradiance level using MPPT-fuzzy,” Int. J. Electr. Comput. Eng., vol. 6, no. 6, pp. 2629-2642, 2016.

[6] M. Junaid and K. Lini, "Different Kinds of Maximum Power Point Tracking Control Method for Photovoltaic Systems : A Review," Arch. Comput. Methods Eng., 2016.

[7] J. P. Ram et al., "Design and overview of maximum power point tracking techniques in wind and solar photovoltaic systems: A review," Renew. Sustain. Energy Rev., vol. 73, pp. 1138-1159, 2017.

[8] H. Sahraoui et al., "Second order sliding mode control of DC-DC converter used in the photovoltaic system according an adaptive MPPT," Int. J. Renew. Energy Res., vol. 6, no. 2, 2016.

[9] R. Ahmad et al., "Power tracking techniques for efficient operation of photovoltaic array in solar applications - A review," Renew. Sustain. Energy Rev., vol. 101, pp. 82-102, 2019.

[10] C. Vadim and N. Ilie, "Photovoltaic system modeling with fuzzy logic based incrimental conductance tracking algorithm," Proc. - Int. Conf. Mod. Power Syst, pp. 1-7, 2017.

[11] M. M. Shebani et al., "Comparing bisection numerical algorithm with fractional short circuit current and open circuit voltage methods for MPPT photovoltaic systems," 2016 IEEE Electr. Power Energy Conf, 2016.

[12] V. R. Kota and M. N. Bhukya, "A novel linear tangents based P \& O scheme for MPPT of a PV system," Renew. Sustain. Energy Rev., no. March, vol. 71, pp. 257-267, 2017.

[13] D. Baimel et al., "Novel optimized method for maximum power point tracking in PV systems using Fractional Open Circuit Voltage technique," Int. Symp. Power Electron. Electr. Drives, Autom. Motion, vol. 2, pp. 889-894, 2016.

[14] K. Amara et al., "Comparative study of three Maximum Power Point Tracking algorithms for photovoltaic modules," vol. 20, pp. 309-318, 2017.

[15] E. Kandemir et al., "A comprehensive overview of maximum power extraction methods for PV systems," Renew. Sustain. Energy Rev., vol. 78, pp. 93-112, 2017.

[16] M. Balamurugan et al.,"Application of soft computing methods for grid connected PV system : A technological and status review," Renewable and Sustainable Energy Reviews, vol. 75, pp. 1493-1508, 2017.

[17] L. Liu et al. "A review of maximum power point tracking methods of PV power system at uniform and partial shading,” Renew. Sustain. Energy Rev., vol. 53, pp. 1500-1507, 2016. 
[18] F. Sayedin et al., "Optimal design and operation of a photovoltaic-electrolyser system using particle swarm optimisation," International journal of sustainable energy, vol. 35, no. 6, 566-582, 2016.

[19] T. S. Babu et al., "Voltage band based improved particle swarm optimization technique for maximum power point tracking in solar photovoltaic system," journal of renewable and sustainable energy, vol. 8, no. 1, 2016.

[20] G. Dileep and S. N. Singh, "Application of soft computing techniques for maximum power point tracking of SPV system," Sol. Energy, vol. 141, pp. 182-202, 2017.

[21] M. A. Danandeh and S. M. G. Mousavi, "Comparative and comprehensive review of maximum power point tracking methods for PV cells,” Renew. Sustain. Energy Rev., vol. 82, 2743-2767, 2018.

[22] M. Kermadi and E. M. Berkouk, "Artificial intelligence-based maximum power point tracking controllers for Photovoltaic systems: Comparative study" Renew. Sustain. Energy Rev., vol. 69, pp. 369-386, 2017.

[23] A. S. Samosir et al., "Modeling and Simulation of Fuzzy Logic based Maximum Power Point Tracking (MPPT) for PV Application," Int. J. Electr. Comput. Eng. (IJECE), vol. 8, no. 3, p. 1315, 2018.

[24] Y. Gopal et al. "Selected Harmonic Elimination for Cascaded Multilevel Inverter Based on Photovoltaic with Fuzzy Logic Control Maximum Power Point Tracking Technique," Technologies, vol. 6, no. 3, p. 62, 2018.

[25] M. Aslam et al., "ScienceDirect Comparative assessment of maximum power point tracking procedures for photovoltaic systems," Green Energy Environ., vol. 2, no. 1, pp. 5-17, 2017.

[26] B. Boukezata et al., "An improved fuzzy logic control MPPT based P\&O method to solve fast irradiation change problem," J. Renew. Sustain. Energy, vol. 8, no. 4, 2016.

[27] I. O. P. C. Series and M. Science, "MPPT based on Fuzzy Logic Controller for Photovoltaic System using PSIM and Simulink," IOP Conference Series: Materials Science and Engineering, 2018.

[28] A. A. Allataifeh et al., "Maximum Power Point Tracking Using Fuzzy Logic Controller under Partial Conditions," Smart Grid Renew. Energy, vol. 6, no. 01, pp. 1-13, 2015.

[29] M. Azharuddin et al., "A Nearly Accurate Solar Photovoltaic Emulator Using a dSPACE Controller for Real-time Control," Electr. Power Components Syst., vol. 44, no. 7, pp. 774-782, 2016.

[30] K. Sangeetha et al., "Fireworks algorithm-based maximum power point tracking for uniform irradiation as well as under partial shading condition," in Artificial Intelligence and Evolutionary Computations in Engineering Systems, pp. 79-88, 2016.

[31] D. Allam et al., "Parameters extraction of the three diode model for the multi-crystalline solar cell/module using Moth-Flame Optimization Algorithm," Energy Convers. Manag., vol. 123, pp. 535-548, 2016.

[32] T. Sudhakar Babu et al., "Modified Particle Swarm Optimization technique based Maximum Power Point Tracking for uniform and under partial shading condition," Appl. Soft Comput. J., vol. 34, pp. 613-624, 2015.

[33] J. Kitson et al., "A photovoltaic panel modelling method for flexible implementation in Matlab/Simulink using datasheet quantities," IEEE Int. Symp. Ind. Electron., pp. 946-951, 2017.

[34] N. A. Zainal et al., "Modelling of Photovoltaic Module Using Matlab Simulink," IOP Conf. Ser. Mater. Sci. Eng., vol. 114, no. 1, 2016.

[35] Z. Layate et al., "ScienceDirect Reactive power compensation control for three phase grid-connected photovoltaic generator," Int. J. Hydrogen Energy, pp. 1-8, 2015.

[36] S. D. Al-majidi et al., "ScienceDirect A novel maximum power point tracking technique based on fuzzy logic for photovoltaic systems," Int. J. Hydrogen Energy, vol. 43, no. 31, pp. 14158-14171, 2018.

[37] B. Bendib et al., "A survey of the most used MPPT methods : Conventional and advanced algorithms applied for photovoltaic systems," Renew. Sustain. Energy Rev., vol. 45, pp. 637-648, 2015. 